\title{
Chemical Composition, Antioxidant, and Anticholine Esterase Activities of Essential Oil of Xylopia aethiopica Seeds
}

\author{
Lateef Adegboyega Sulaimon, Rahmat Adetutu Adisa', Efereo Martins Obuotor², Modinat Olasunkanmi Lawal, \\ Abdullahi I. Moshood, Nura H. Muhammad
}

Department of Chemical Sciences, Crescent University, Abeokuta, 'Department of Biochemistry, University of Lagos, Lagos, ${ }^{2}$ Department of Biochemistry, Obafemi Awolowo University, Ile-Ife, Nigeria

\begin{abstract}
Background: Xylopia aethiopica is well known to treat neurodegenerative diseases in traditional medicine and there is no scientific evidence for this claim. Objective: The current research aimed at investigating chemical characterization, antioxidant, and anticholine esterase activity of the essential oil from $X$. aethiopica. Materials and Methods: Essential oil extraction was carried out by the use of the steam distillation method in a modified Clevenger-type apparatus. The chemical composition of the essential oil from seeds of $X$. aethiopica (African pepper) was determined using gas chromatography coupled with mass spectrometry (GC-MS) and its potentials as antioxidant and anticholine esterase were evaluated for the first time. Results: The oil yield was $5.2 \%(\mathrm{v} / \mathrm{W})$ in $X$. aethiopica. The GC-MS analysis identified a total of 52 compounds corresponding to $100 \%$ of the total oil in $X$. aethiopica. The major constituents of $X$. aethiopica essential oil are terpinen-4-ol (11.88\%), $\alpha$-terpineol (5.93\%), cyclohexane methanol (4.79\%), and $\beta$-copaene (4.74\%). The most abundant classes of compounds from theessential oilwere oxygenatedmonoterpenes (MT) which amounted to $(37.6 \%)$, followed by oxygenated sesquiterpenes $(29.61 \%)$, sesquiterpenes $(14.67 \%)$, oxygenated diterpenes $(9.05 \%)$, nonterpenoid aliphatic and aromatic hydrocarbons $(4.81 \%)$, diterpenes $(3.8 \%)$, and MT $(0.47 \%)$ of all the identified constituents. A significant antioxidant $\left(I C_{50}\right.$ value of 2,2-diphenyl-1-picrylhydrazyl $\left.=2.19 \pm 0.09 \mathrm{mg} / \mathrm{mL}\right)$ and anticholine esterase activity $\left(I C_{50}=1.21 \pm 0.06 \mathrm{mg} / \mathrm{mL}\right)$ was obtained for the essential oil of $X$. aethiopica. Conclusion: The study established the chemical composition, antioxidant, and anticholine esterase activities of the essential oil of the plant seeds.

Key words: Anticholineesterase, antioxidant, monoterpenes, sesquiterpenes, Xylopia aethiopica
\end{abstract}

\section{SUMMARY}

- Steam distillation method was used to extract essential oil from the seeds of Xylopia aethiopica with the yield of 5.2\% (VM)

- Fifty two (52) compounds were identified in $X$. aethiopica essential oil. Terpinen-4-ol, $\alpha$-terpineol, cyclohexane methanol and $\beta$-copaene are the major constituents in $X$. aethiopica essential oil

- Essential oil of $X$. aethiopica seeds showed a significant antioxidant and Anticholine esterase activity.

Abbreviations Used: ROS: Reactive oxygen species, AD: Alzheimer's disease, DPPH: 2,2-diphenyl-1-picrylhydrazyl, AChE: Acetyl choline esterase, BChE: Butyryl choline esterase, DTNB: 5, 5'-Dithiobis-(2-nitrobenzoic acid), GC: Gas chromatography, GC-MS: Gas chromatography-mass spectrometry, FRAP: Ferric-reducing antioxidant power, FID: Flame ionizing detector, TAC: Total antioxidant capacity, MT: Monoterpenes, OM: Oxygenated monoterpenes, ST: Sesquiterpenes, OS: Oxygenated sesquiterpenes, $\mathrm{NH}$ : Nonterpenoid hydrocarbons, DT: Diterpene, OD: Oxygenated diterpenes, OST: Oxygenated sesterterpene, NS: Not significant, SD: Standard deviation, AAE: Ascorbic acid equivalent, RT: Retention time, RI: Retention index.

\section{Correspondence:}

Mr. Lateef Adegboyega Sulaimon,

Department of Chemical Sciences, Crescent

University, Abeokuta, Nigeria.

E-mail: adlat4best@yahoo.com

DOI: $10.4103 / p r . p r \_47 \_19$

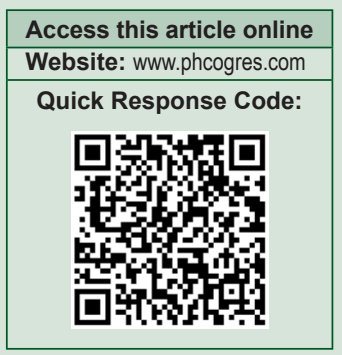

\section{INTRODUCTION}

A brief history of medicine demonstrates the use of herbal medicine for the effective treatment of various ailments. Herbal medicine has been used since long in various forms including the decoction, powdered sample, oleoresins, crude extracts, fixed oil, essential oil, etc. ${ }^{[1]}$ Various plants have been used in multiple types of food items for preservation and therapeutic effects. ${ }^{[2]}$ In this regard, essential oils have been manifested by several reporters to play a major role. Essential oils have the property to attenuate the effects of free radicals, for example, reactive oxygen species (ROS) which are derived from the metabolism of oxygen and exogenous agents. ${ }^{[3]}$ ROS are responsible for wide variety of diseased conditions including oxidative stress and nervous disorders. ${ }^{[4]}$ Essential oils are well known for their radicals scavenging properties and amelioration of various cognitive disorders. Among the cognitive disorders, Alzheimer's disease (AD) is the most common in elderly people. ${ }^{[5]}$ One of the best therapeutic approaches for AD is to increase the concentration of the neurotransmitter (Acetylcholine) by inhibiting the enzyme (acetyl cholinesterase) responsible for its breakdown. Various drugs originated either from natural or synthetic sources are being used for the management of $\mathrm{AD}$ and other nervous disorders. ${ }^{[6]}$ Similarly, it has also been reported that oxidative stress are responsible for wide variety of mental diseases due to neuronal degeneration and other factors. Oxidative stress is mainly developed due to increase in concentration of free radicals within the body. The free radicals have been reported by numerous researchers to possess multiple destructive properties, and the research interest has been focused on scavenging the free radicals and avoiding their deteriorating effects. ${ }^{[7]}$ In this context, investigators are trying to explore more and more sources of natural and synthetic bioactive principles. ${ }^{[8]}$ The natural drugs are being preferred over the synthetic due to their negligible harmful and deleterious effects. ${ }^{[9]}$ That is why researchers are trying to explore novel sources of natural medicine. ${ }^{[10-18]}$ Among the natural sources, herbal medicines have been shown promising results due to the presence of numerous secondary metabolites and essential

This is an open access journal, and articles are distributed under the terms of the Creative Commons Attribution-NonCommercial-ShareAlike 4.0 License, which allows others to remix, tweak, and build upon the work non-commercially, as long as appropriate credit is given and the new creations are licensed under the identical terms.

\section{For reprints contact: reprints@medknow.com}

Cite this article as: Sulaimon LA, Adisa RA, Obuotor EM, Lawal MO, Moshood Al, Muhammad $\mathrm{NH}$. Chemical composition, antioxidant, and anticholine esterase activities of essential oil of xylopia aethiopica seeds. Phcog Res 2020;12:112-8. 
oil. Essential oils isolated from various plants have been reported to possess marked acetyl cholinesterase inhibitory and radicals scavenging potentials. ${ }^{[19-21]}$ Traditional knowledge also demonstrates the use of essential oil for various nervous system disorders. ${ }^{[22]}$

Xylopia aethiopica is a deciduous tree, belongs to the family Annonaceae. It is popularly known as "African pepper," "Ethiopian pepper" or "Guinea pepper." It is a small tree which can reach $20 \mathrm{~m}$ in height. Its fruits are used as spice and stimulate the appetite. It is widely distributed in the West African rainforest from Senegal to Sudan in Eastern Africa and down to Angola in Southern Africa. ${ }^{[23]}$ Its organs are used in African traditional medicine, only or in association with other plants for the treatment of the skin infections, cholera, dysentery, and the hernia. ${ }^{[24]}$

$X$. aethiopica is a medicinal plant of great repute in West Africa and contains a variety of complex chemical compounds. ${ }^{[25]}$ Almost every part of the plant is used in traditional medicine for managing various ailments, including skin infections, candidiasis, dyspepsia, neurodegenerative disease, cough, and fever. ${ }^{[26]}$ A major advantage of using $X$. aethiopica as a food preservative is that foods preserved by this spice may qualify as a functional food since it has many health benefits such as anti-tumor, anti-asthmatic, anti-inflammatory, antioxidant, antimicrobial, ${ }^{[27]}$ hypotensive, and coronary vasodilators effects. ${ }^{[28]}$ The seeds contain bitter principles, alkaloids, terpenes, glycosides, saponins, tannins, sterols, carbohydrate, protein and free fatty acid, mucilage, and acidic compounds; some of which might be responsible for its reported uses. ${ }^{[29]}$ To date, the chemical composition of essential oil of $X$. aethiopica seeds has not been reported or evaluated for any pharmacological activity. Based on the literature survey and medicinal importance of $X$. aethiopica, the current investigational study was arranged to isolate the essential oil, analyze the chemical composition, and to evaluate for the anticholinesterase and antioxidant potentials, which may be a possible remedy for oxidative stress and nervous system disorders.

\section{MATERIALS AND METHODS}

\section{Plant material}

Dried fruits of $X$. aethiopica were purchased from the Itoku market, Abeokuta, Ogun State, Nigeria. The fruits were identified and authenticated at the Biological Sciences Department, Crescent University Abeokuta with a voucher number CUH 1220.

\section{Chemicals}

DPPH (Sigma Aldrich, Germany), $\mathrm{K}_{2} \mathrm{~S}_{2} \mathrm{O}_{4}$ (Riedel-de Haen Germany), Folin Ciocalteu reagent (Merck Co. Germany), acetylcholinesterase (AChE) (Electric eel type-VI-S, Sigma-Aldrich Germany), butyrylcholinesterase (BChE) (Equine serum Lyophilized Sigma-Aldrich), Acetylthiocholine iodide (Sigma-Aldrich Germany), Butyrylthiocholine Iodide (Sigma-Aldrich), DTNB (Sigma-Aldrich Germany). The entire chemicals used were of analytical grade.

\section{Essential oil extraction}

Extraction of the essential oil was carried out in the Department of Biochemistry and Molecular Biology, Obafemi Awolowo University, Ile-Ife, Osun State. The seeds were separated from the shaft and grinded to a coarse powder using a manual blender. Two kilogram $(2 \mathrm{~kg})$ of the coarse powder was weighed and loaded into a flat-bottomed distillation tank that formed part of the modified Clevenger-type apparatus. ${ }^{[30]}$ Four liters of water was poured into the tank and the rid secured tightly. The powdered seeds were then subjected to steam distillation with the collection of the oil starting after a heating time of $50 \mathrm{~min}$ and continued until no more essential oil was obtained (5-8 h). The volatile oil was collected from the top of the hydrosol and dried over anhydrous sodium sulfate $\left(\mathrm{Na}_{2} \mathrm{SO}_{4}\right)$. The oil was filtered using Whatman filter paper (No. 1), weighed and collected into $3 \mathrm{ml}$ airtight glass vials. The essential oil was then stored at $-20^{\circ} \mathrm{C}$ in a freezer until when required for chemical analysis.

\section{Gas chromatography analysis}

The gas chromatography (GC) analysis of essential oil was carried out through gas chromatograph Agilent USB-393752 (Agilent Technologies, Palo Alto, CA, USA) with HHP-5MS 5\% phenyl-methyl siloxane capillary column $(30 \mathrm{~m} \times 0.25 \mathrm{~mm} \times 0.25 \mu \mathrm{m}$ film thickness; Restek, Bellefonte, PA, USA) connected with flame ionizing detector. The oven was set at temperature of $50^{\circ} \mathrm{C}$ for $1 \mathrm{~min}$ and then increased to $100^{\circ} \mathrm{C}$ at the rate of $5^{\circ} \mathrm{C} / \mathrm{min}$ for $10 \mathrm{~min}$ and lastly to $280^{\circ} \mathrm{C}$ at the rate of $10^{\circ} \mathrm{C} / \mathrm{min}$ for $20 \mathrm{~min}$. The temperature of injector and detector were maintained at $220^{\circ} \mathrm{C}$ and $290^{\circ} \mathrm{C}$ correspondingly. The flow rate of carrier gas, i.e., helium was $1 \mathrm{ml} / \mathrm{min}$ and the diluted samples (1/1000 inn-pentane, v/v) of $1 \mu \mathrm{l}$ were manually injected in the split-less mode.

\section{Gas chromatography-mass spectrometry analysis}

The gas chromatography-mass spectrometry (GC/MS) of the essential oil was performed through USB-393752 gas chromatograph (Agilent Technologies, Palo Alto, CA, USA) with an HHP-5MS 5\% phenyl-methyl siloxane capillary column (30 m $\times 0.25 \mathrm{~mm} \times 0.25 \mu \mathrm{m}$ film thickness; Restek, Bellefonte, PA, USA) outfitted with an Agilent HP-5973 mass selective detector in the electron impact mode (Ionization energy: $70 \mathrm{eV}$ ) working under the experimental conditions as those maintained for GC.

\section{Identification of components}

The recognition of all the major constituents of oil was performed by comparing their retention times with the authentic compounds in the literature. Identification of compounds was further processed through the spectral data obtained from the Wiley and NIST libraries as well as fragmentation patterns comparisons of the mass spectra with data reported in literature or with those of mass spectra from literature. ${ }^{[31,32]}$

\section{Anticholinesterase assay}

Anticholinesterase (AChE and BChE inhibitions) activity was performed for the essential oil of $X$. aethiopica by spectrophotometric analysis following the method of Ellman's assay. ${ }^{[33]}$ The substrates used were acetylthiocholine iodide and butyrylthiocholine iodide. Briefly, $5 \mu \mathrm{L}$ of $0.03 \mathrm{U} / \mathrm{mL}$ AChE and $0.01 \mathrm{U} / \mathrm{mL} \mathrm{BChE}$ were taken in a cuvette and $205 \mu \mathrm{L}$ of essential oil having concentration of $(156.25-5000) \mu \mathrm{g} / \mathrm{mL}$ were transferred to them using micropipette. Similarly, $100 \mu \mathrm{L}$ of DTNB was also added to this afterward. The mixtures obtained were kept in water bath for $15 \mathrm{~min}$ at the temperature of $30^{\circ} \mathrm{C}$. After incubation, $200 \mu \mathrm{L}$ of the Substrates were added to the mixture to optimize the reaction. A double beam spectrophotometer was used to measure the reaction time at $412 \mathrm{~nm}$ through a double beam spectrophotometer (Thermo electron corporation USA). Absorption values were obtained for $4 \mathrm{~min}$. Meanwhile, the yellow color mixtures indicated the formation of 5-thio-2-nitrobenzoate anion as a reaction product of thiocholines and DTNB. White assay was also performed without enzymes and plant samples to check the non-enzymatic hydrolysis of the substrate. The mixture which contained all the components excluding essential oil was marked as control. Percentage inhibition was recorded as follows:

$\%$ inhibition $=(\mathrm{E}-\mathrm{S}) / \mathrm{E} \times 100$.

Where $E$ is the activity of the enzyme without sample and $S$ is the activity of enzyme with the test sample.

\section{2,2-Diphenyl-1-picrylhydrazyl radical scavenging assay}

The 2,2-diphenyl-1-picrylhydrazyl (DPPH) radical scavenging potential was evaluated for essential oil of $X$. aethiopica following 
the previously described procedure. ${ }^{[34]} \mathrm{DPPH}$ solution $(0.004 \%)$ was prepared in methanol to get a deep violet color solution. Similarly, stock solution of essential oil was prepared in ethanol having concentration of $1 \mathrm{mg} / \mathrm{mL}$. The stock solution was serially diluted to get the concentrations of $156.25-5000 \mu \mathrm{g} / \mathrm{mL}$. Afterward, $0.1 \mathrm{~mL}$ of each concentration was added to the $3 \mathrm{~mL}$ of DPPH solution. The mixture obtained was incubated at $23^{\circ} \mathrm{C}$ for $30 \mathrm{~min}$ in dark. After incubation, the absorbance of each sample was recorded at the wavelength of $517 \mathrm{~nm}$ using double beam spectrophotometer. Ascorbic acid was used as the positive control. All the samples were processed in triplicates and the percent activity was recorded as mean \pm standard error of the mean. The percent radical scavenging potential was figured out using the following formula;

$\left(\left[A_{c}-A_{0}\right] / A_{c}\right) \times 100$; where $A_{c}=$ Absorbance of control and $A_{0}=$ Absorbance of sample.

\section{Estimation of $\mathrm{IC}_{50}$ values}

The median inhibitory concentration, i.e., $\mathrm{IC}_{50}$ values of $\mathrm{AChE}, \mathrm{BChE}$, and DPPH were determined by a linear regression analysis of the percent inhibition versus the concentrations of test samples through MS Excel program.

\section{Ferric-reducing antioxidant power assay}

Ferric-reducing antioxidant power (FRAP) assay of extracts was carried out according to method. ${ }^{[35]}$ The FRAP reagent consists of $300 \mathrm{mM}$ acetate buffer $\mathrm{pH}$ 3.6, $10 \mathrm{mM}$ TPTZ (2, 4, 6-tripyridyl-s-triazine). and 20 mM FeCl $3.6 \mathrm{H}_{2} \mathrm{O}$ solution. A volume of $150 \mu \mathrm{l}$ plant extracts were mixed to FRAP reagent, allowed to stand for $6 \mathrm{~min}$ and absorbance was noted at $593 \mathrm{~nm}$ in a microplate reader. The antioxidant activity of the extract was expressed as the number of mg equivalents to ascorbic acid (AAE)/g extract. All the experiments were carried out in triplicates.

\section{Total antioxidant capacity}

Total iron-reducing power assay was carried out by taking $100 \mu \mathrm{l}$ of extract $(2 \mathrm{mg} / \mathrm{ml})$ in individual test tubes added $2.5 \mathrm{ml}$ buffer, $1.5 \mathrm{ml}$ potassium ferrocyanide (1\%), and $100 \mu \mathrm{l} \mathrm{FeCl}$ then the reaction mixtures were incubated for $30 \mathrm{~min}$ at RT. The absorbance was noted at $700 \mathrm{~nm}$ in a microplate reader. ${ }^{[35]}$ The antioxidant activity of the extract was expressed as the number of mg AAE/g extract. All the experiments were carried out in triplicates.

\section{Statistical data analysis}

All the tests were conducted in triplicate and the values were tabulated as mean \pm standard deviation.

\section{RESULTS AND DISCUSSION}

In the current investigational study, the essential oil obtained by steam distillation from seeds of $X$. aethiopica yielded 5.2\% (v/w) on dry weight. This result is comparable to those previously obtained by Tegang et al. ${ }^{[36]}$ who found extraction yield of $4.2 \%$ for the essential oil of dried fruits of $X$. aethiopica from Cameroon. Bakarnga-Via et al. ${ }^{[37]}$ earlier reported the yields of $3.57 \%$ and $4.68 \%$, for dried fruits of $X$. aethiopica from Chad and Cameroon, respectively. However, the extraction yields of the essential oil of dried fruits of $X$. aethiopica obtained from the local market in Keffi, Nasarawa State, Nigeria, was lower $1.2 \%{ }^{[38]}$

Antioxidants play a crucial role in the management and treatment of neurodegenerative conditions, as the role of free radicals in such conditions has been well established since brain cells consume a high amount of oxygen. ${ }^{[39]}$ The DPPH radical scavenging activity, total antioxidant capacity (TAC) and FRAP assays exhibit the antioxidant property of the essential oil used in this study. The stable organic radical
DPPH has been widely employed in studies of the antioxidant capacity of essential oil. ${ }^{[40]}$ The DPPH (1, 1-diphenyl-2 picrylhydrazyl) test measures the hydrogen atom or electron donor capacity of the essential oil to the stable radical DPPH formed in solution. ${ }^{[41]}$ It also measures the ability of the essential oil to scavenge free radicals in solution.

The radical scavenging potential of volatile oil was studied based on spectrophotometric analysis. The source of free radicals employed was $\mathrm{DPPH}$, which has maximum absorbance value at $517 \mathrm{~nm}$. After getting scavenged by antioxidant compounds, the color of DPPH (violet) solution changes into yellow. Change in the color results in decrease of absorbance values, which is directly proportional to the amount of radical scavenging compounds in the solution. ${ }^{[42,43]}$ In our current investigational study, the free radicals scavenging assay of essential oil of $X$. aethiopica against $\mathrm{DPPH}\left(\mathrm{IC}_{50}\right.$ value $\left.=2.19 \pm 0.09 \mathrm{mg} / \mathrm{ml}\right)$ was significant and almost comparable with the positive control $\left(\mathrm{IC}_{50}\right.$ value $=0.013 \mathrm{mg} / \mathrm{ml}$ ) From Table 1, it is clear that essential oil exhibited marked antioxidant potential with TAC and FRAP values of $10.92 \pm 0.63 \mathrm{mg} \mathrm{AAE} / \mathrm{g}$ and $10.03 \pm 0.25 \mathrm{mg} \mathrm{AAE} / \mathrm{g}$, respectively. Our findings are in contrary to the study of Adefegha et al., ${ }^{[44]}$ who reported high $\mathrm{IC}_{50}$ values of $37.3 \mu \mathrm{L} / \mathrm{L}$ and $62.5 \mu \mathrm{L} / \mathrm{L}$ for DPPH and nitric oxide radical scavenging activities of $X$. aethiopica, respectively.

The available literatures on etiology of diseases demonstrate multiple causative agents responsible for specific disease. ${ }^{[45]}$ In the context of $\mathrm{AD}$, numerous investigators have reported the role of various causative agents along with various successful approaches. ${ }^{[46]}$ Like all neurodegenerative disorders, the free radicals have a prominent role in the induction and progression of $\mathrm{AD} .{ }^{[47]} \mathrm{By}$ avoiding or attenuating the causative agents, one can hinder the progression of a specific disease. In the case of neurodegenerative disorders, the scavenging of free radicals can be a vital target. Various researchers have demonstrated the effective role of natural antioxidants, especially the essential oil to combat the free radicals. ${ }^{[48]}$ Similarly, one of the most widely employed treatment strategies for $\mathrm{AD}$, i.e., the inhibition of $\mathrm{AChE}$ to increase the concentration of neurotransmitter is highly recommended. ${ }^{[49]}$ The inhibition of AChE and BChE, however, has been accepted as an effective approach toward the treatment and management of AD. ${ }^{[50,51]}$ The anticholinesterase and antioxidant potentials of essential oil of $X$. aethiopica seeds are summarized in Table 1 . Based on the $\mathrm{IC}_{50}$ values for the concentration-dependent inhibition of $\mathrm{AChE}$ and $\mathrm{BChE}$, the essential oil of $X$. aethiopica seeds showed high $\mathrm{AChE}\left(\mathrm{IC}_{50}=1.21 \pm 0.06 \mathrm{mg} /\right.$ $\mathrm{mL})$ and $\mathrm{BChE}\left(\mathrm{IC}_{50}=4.39 \pm 1.38 \mathrm{mg} / \mathrm{mL}\right)$ inhibitory effects. Adeniyi et al. ${ }^{[44]}$ previously reported similar results of the inhibitory effects of $X$. aethiopica on $\mathrm{AChE}\left(\mathrm{IC}_{50}=18.5 \mu \mathrm{L} / \mathrm{L}\right)$ and $\mathrm{BChE}\left(\mathrm{IC}_{50}=26.4 \mu \mathrm{L} / \mathrm{L}\right)$. It is worth noting that the essential oil of $X$. aethiopica seeds showed an AChE inhibition stronger than the BChE inhibition. Therefore, the oil may be of immense therapeutic importance in that they may enhance nerve cell communication, improve cognitive effects and manage AD. ${ }^{[52,53]}$ The essential oil obtained from various plants possesses marked anti-Alzheimer's potential due to the presence of wide variety of valuable compounds in them. ${ }^{[54,55]}$ The anticholinesterase activity of essential oil

Table 1: Anticholine esterase and antioxidant activity of essential oil of Xylopia aethiopica

\begin{tabular}{llc}
\hline Assays & Units & Mean \pm SD \\
\hline Acetylcholine esterase inhibition & $\mathrm{IC}_{50}(\mathrm{mg} / \mathrm{ml})$ & $1.21 \pm 0.06$ \\
Butyrylcholine esterase inhibition & $\mathrm{IC}_{50}(\mathrm{mg} / \mathrm{ml})$ & $4.39 \pm 1.38$ \\
DPPH radical scavenging activity & $\mathrm{IC}_{50}(\mathrm{mg} / \mathrm{ml})$ & $2.19 \pm 0.09$ \\
TAC & mgAAE $/ \mathrm{g}$ & $10.92 \pm 0.63$ \\
FRAP & mgAAE $/ \mathrm{g}$ & $10.03 \pm 0.25$ \\
\hline
\end{tabular}

TAC: Total antioxidant capacity; DPPH: 1, 1 -diphenyl-2 picrylhydrazyl; FRAP: Ferric-reducing antioxidant power; SD: Standard deviation; $\mathrm{IC}_{50}$ : Half maximal inhibitory concentration 
of $X$. aethiopica might be due to its hydrophobic nature because of the good affinity of hydrophobic active site of AChE. ${ }^{[6,57]}$

The GC-MS analysis of essential oil of X. aethiopica demonstrates a total of 52 components as shown in Table 2. The ion chromatogram indicating 62 phyto-components in the essential oil of $X$. aethiopica (with 62 peaks) is shown in Figure 1. However, some of the components appeared more than once with different retention time and this accounts for fifty-two different components of $X$. aethiopica essential oil in the present study. Some of the most common components of essential oil, i.e., terpinen-4-ol, carveol, eugenol, $\alpha$-copaene, $\alpha$-terpineol, Caryophyllene, $\alpha$-muurolene, guaiol, thunbergol, geraniol, farnesol acetate, spathulenol, and isolongifolol have been found in the essential oil of X. aethiopica seeds. Ayedoun et al. ${ }^{[58]}$ identified elemol and guaiol (among other terpenes) in the essential oil of the fruit of X. aethiopica from the Republic of Benin. Previous investigations on the essential oil of the fruits of $X$. aethiopica from various areas revealed that they mainly consist of $\alpha$-and $\beta$-pinene, myrcene, $p$-cymene, limonene, linalool, terpinen- 4 -ol, $\alpha$-terpineol, and 1,8-cineole. ${ }^{[59-62]}$ Cumine aldehyde and sabinene have been identified in the fruit essential oil of $X$. aethiopica from Nigeria ${ }^{[63]}$ in contrast to our study, where both are practically absent. Furthermore, $\beta$-pinene, which

Table 2: List of components of essential oil of Xylopia aethiopica

\begin{tabular}{|c|c|c|c|c|c|}
\hline Number & $\mathrm{RT}$ (min) & Compound name & $\mathbf{R I}$ & Class & Concentration (\%) \\
\hline 1 & 5.149 & 4-Isopropyl-1-methyl-2-cyclohexen-1-ol & 1109 & OM & 1.50 \\
\hline 2 & 5.341 & Pinocarveol & 1131 & $\mathrm{OM}$ & 4.39 \\
\hline 3 & 5.455 & Dihydrocarveol & 1196 & $\mathrm{OM}$ & 1.88 \\
\hline 4 & 5.817 & Terpin-4-ol & 1137 & $\mathrm{OM}$ & 11.88 \\
\hline 5 & 6.063 & a-Terpineol & 1143 & $\mathrm{OM}$ & 5.93 \\
\hline 6 & 6.184 & Myrtenol & 1191 & $\mathrm{OM}$ & 3.90 \\
\hline 7 & 6.274 & Piperitol & 1175 & $\mathrm{OM}$ & 1.31 \\
\hline 8 & 6.316 & Carveol & 1206 & $\mathrm{OM}$ & 0.85 \\
\hline 9 & 6.403 & 3-Allyl-2,6,6-trimethyl-Bicycloheptane & 1187 & $\mathrm{NH}$ & 3.13 \\
\hline 10 & 6.933 & Myrtenal & 1136 & $\mathrm{OM}$ & 2.12 \\
\hline 11 & 7.089 & 2H-Inden-2-one & 1237 & $\mathrm{OM}$ & 0.33 \\
\hline 12 & 7.168 & Naphthalene & 1185 & $\mathrm{NH}$ & 0.37 \\
\hline 13 & 7.306 & Perillic Alcohol & 1261 & $\mathrm{OM}$ & 1.57 \\
\hline 14 & 7.482 & p-Ethylguaiacol & 1303 & $\mathrm{NH}$ & 1.23 \\
\hline 15 & 7.553 & 3-Isopropenyl-5-methyl-1-cyclohexene & 990 & MT & 0.47 \\
\hline 16 & 7.737 & a-Copaene & 1221 & ST & 2.95 \\
\hline 17 & 7.997 & Myrtenyl acetate & 1314 & $\mathrm{OM}$ & 0.46 \\
\hline 18 & 8.063 & Eudesma-4 (14), 11-diene & 1469 & ST & 1.45 \\
\hline 19 & 8.280 & $\beta$-Copaene & 1216 & ST & 5.04 \\
\hline 20 & 8.382 & Eugenol & 1392 & $\mathrm{OM}$ & 0.63 \\
\hline 21 & 8.509 & Caryophyllene & 1494 & ST & 1.26 \\
\hline 22 & 8.558 & Cis-Isoeugenol & 1410 & $\mathrm{OM}$ & 0.85 \\
\hline 23 & 8.896 & $\Upsilon$-Muurolene & 1435 & ST & 1.52 \\
\hline 24 & 8.938 & 1H-3a, 7-methanoazulene & 1398 & ST & 0.79 \\
\hline 25 & 9.128 & a-Muurolene & 1440 & ST & 0.49 \\
\hline 26 & 9.357 & Eremophila-1 (10), 11-diene & 1474 & ST & 0.73 \\
\hline 27 & 9.949 & Aromadendrene oxide & 1462 & OS & 0.90 \\
\hline 28 & 10.038 & (-)-Spathulenol & 1536 & OS & 4.49 \\
\hline 29 & 10.407 & 11-a-Hydroxy-pregn-4-ene-3,20-dione & 2435 & OD & 1.91 \\
\hline 30 & 10.582 & Cyclohexane methanol & 1522 & OS & 4.79 \\
\hline 31 & 10.817 & Aristolene epoxide & 1293 & OS & 0.87 \\
\hline 32 & 10.978 & Guaiol & 1614 & OS & 1.47 \\
\hline 33 & 11.042 & Naphthalen-2-ol & 1690 & OS & 2.47 \\
\hline 34 & 11.211 & Alloaromadendrene & 1386 & ST & 0.44 \\
\hline 35 & 11.550 & $\Upsilon$-Eudesmol & 1626 & OS & 2.21 \\
\hline 36 & 11.676 & Alloaromadendreneoxide & 1386 & OS & 1.68 \\
\hline 37 & 11.930 & Aromadendrene & 1462 & OS & 2.37 \\
\hline 38 & 12.022 & Cyclopropane carboxylic acid ester & 2345 & OD & 1.03 \\
\hline 39 & 12.145 & a-Eudesmol & 1598 & OS & 2.74 \\
\hline 40 & 12.234 & Eudesm-4 (14)-en-11-ol & 1593 & OS & 2.40 \\
\hline 41 & 12.331 & 12-Oxabicyclo[9.1.0] dodeca-3,7-diene & 1592 & OS & 0.66 \\
\hline 42 & 12.435 & Bicyclo[5.3.1] undec-1-en-8-ol & 1754 & OS & 2.41 \\
\hline 43 & 12.892 & Trans-Geranyl geraniol & 2192 & OD & 0.85 \\
\hline 44 & 14.739 & Farnesol acetate & 1834 & OS & 0.15 \\
\hline 45 & 16.524 & Labd-4-ene & 1978 & OD & 4.14 \\
\hline 46 & 17.167 & Thunbergol & 2211 & OD & 0.07 \\
\hline 47 & 18.017 & 1-Phenanthrene carboxylic acid & 2193 & OD & 0.15 \\
\hline 48 & 19.127 & Kauran-16-ol & 1934 & OD & 0.71 \\
\hline 49 & 19.370 & Labd-14-en-3-one & 2149 & OD & 0.19 \\
\hline 50 & 20.033 & Kaur-16-ene & 1789 & DT & 3.80 \\
\hline 51 & 21.268 & Ethanol, 2-butoxy phosphate ester & 0 & $\mathrm{NH}$ & 0.08 \\
\hline 52 & 21.325 & 10-12-Pentacosadiynoic acid & 2897 & OST & NS \\
\hline
\end{tabular}

RT: Retention time; RI: Retention index; MT: Monoterpenes; ST: Sesquiterpenes; OM: Oxygenated MT; NH: Nonterpenoid hydrocarbon; OS: Oxygenated ST; OD: Oxygenated diterpenes; DT: Diterpene; OST: Oxygenated sesterterpene 


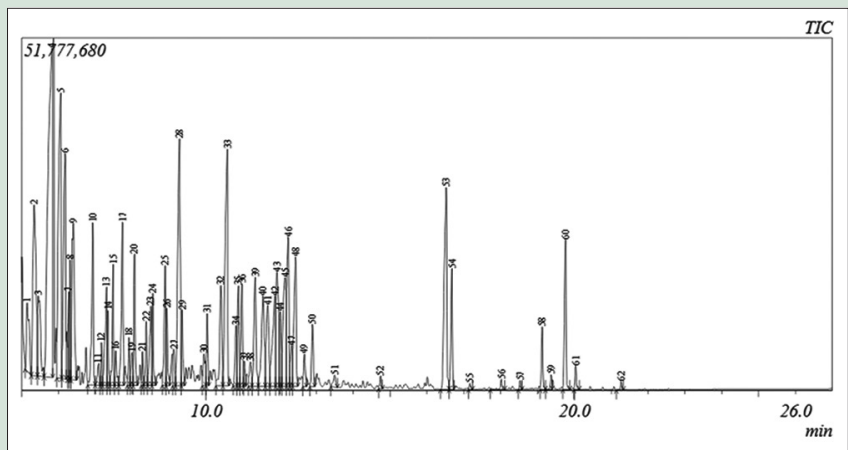

Figure 1: Representative total ion chromatogram of Xylopia aethiopica essential oil

is predominantly present in essential oil of $X$. aethiopica fruits from Ghana ${ }^{[64]}$ and Cameroon, ${ }^{[36]}$ is not found in essential oil of $X$. aethiopica seeds. Some of these components have been reported previously by other investigators to possess antioxidant and anticholinesterase potentials. ${ }^{[65-73]}$ Going to the detail of various components of essential oil of X. aethiopica, it is clear that the marked antioxidant and anticholinesterase activities shown by the essential oil is observed due to the presence of wide variety of compounds in it.

Fifty-two constituents, representing $100 \%$ of $X$. aethiopica essential oil, were identified in the present study [Table 2]. The major components of essential oil of $X$. aethiopica seeds are terpinen-4-ol (11.88\%), $\alpha$-terpineol $\quad(5.93 \%), \quad \beta$-copaene $\quad(5.04 \%), \quad$ cyclohexane methanol (4.79\%), (-)-spathulenol (4.49\%), pinocarveol (4.39\%), and labd-4-ene (4.14\%). Karioti et al., ${ }^{[64]}$ identified 93 compounds from essential oil of leaves, barks of the stem and root, fresh and dried fruits of $X$. aethiopica from Ghana with the predominant compounds such as $\beta$-pinene, trans-m-metha-1 (7), 8-diene, germacrene D. Whereas, Tegang et al., ${ }^{[36]}$ identified seventy (70) components in the essential oil of $X$. aethiopica fruit from Cameroon which mainly consists of $\beta$-pinene, $\beta$-phellandrene, bisabolene, and $\alpha$-pinene while Adefegha et al., ${ }^{[44]}$ detected 30 phyto-compounds in the essential oil of $X$. aethiopica from Nigeria, having eugenol, terpinen-4-ol, germacrene D, (-) spathulenol, and limonene as its major constituents. Different parts of the plant and geographic origins may be responsible for variation in the chemicals and aromatic components of essential oil of $X$. aethiopica obtained from different regions.

Data from Table 3 indicated that eight classes of compounds have been detected from $X$. aethiopica essential oil like monoterpenes (MT), oxygenated monoterpenes (OM), sesquiterpenes (ST), oxygenated sesquiterpenes (OS), nonterpenoid hydrocarbons (NH), diterpene (DT), oxygenated diterpenes (OD), and oxygenated sesterterpene. The essential oil obtained from seeds of $X$. aethiopica has been found to be rich in OM which amounted to (37.6\%), followed by OS $(29.61 \%)$, ST (14.67\%), OD (9.05\%), NH (4.81\%), DT (3.8\%), and MT (0.47\%). This is in contrast to previous studies that reported the absence/traces of diterpenes and aliphatic esters in the essential oil of X. aethiopica. ${ }^{[36,44,64]}$

\section{CONCLUSION}

Essential oil isolated for the first time from the seeds of $X$. aethiopica and its chemical composition demonstrates that $X$. aethiopica is a source of valuable volatile components. Based on the anticholinesterase and antioxidant results of essential oil, it can be concluded that $X$. aethiopica seeds may be an effective source of compounds that may lead to possible palliative therapy and cure of neurodegenerative and oxidative stress-related diseases.
Table 3: Major class of compounds in essential oil of Xylopia aethiopica

\begin{tabular}{lc}
\hline Class of compounds & Concentration (\%) \\
\hline OM & 37.60 \\
MT & 0.47 \\
ST & 14.67 \\
OS & 29.61 \\
DT & 3.80 \\
OD & 9.05 \\
NH & 4.81 \\
OST & NS \\
Total & 100
\end{tabular}

MT: Monoterpenes; ST: Sesquiterpenes; OM: Oxygenated MT;

NH: Nonterpenoid hydrocarbon; OS: Oxygenated ST; OD: Oxygenated diterpenes; DT: Diterpene; OST: Oxygenated sesterterpene

\section{Acknowledgements}

The authors appreciate the technical assistance of Mr. W. A. Idris and other technical staff of the Department of Chemical Sciences, College of Natural and Applied Sciences, Crescent University, Abeokuta.

\section{Financial support and sponsorship}

Nil.

\section{Conflicts of interest}

There are no conflicts of interest.

\section{REFERENCES}

1. Van Wyk BE, Wink M. Medicinal Plants of the World: An Illustrated Scientific Guide to Important Medicinal Plants and their Uses. Portland, USA: Timber Press; 2004.

2. Samant S, Palni L, Kumar S, Kukreja A, Dwivedi S, Singh A. Diversity, distribution and indigenous uses of essential oil-yielding medicinal plants of the Indian Himalayan region. J Med. Arom. Plant Sci 2000;22:671-84

3. Ruberto G, Baratta MT. Antioxidant activity of selected essential oil components in two lipid model systems. Food Chem 2000;69:167-74.

4. Kumar H, Lim HW, More SV, Kim BW, Koppula S, Kim IS, et al. The role of free radicals in the aging brain and Parkinson's Disease: Convergence and parallelism. Int J Mol Sci 2012;13:10478-504.

5. Mukherjee PK, Kumar V, Mal M, Houghton PJ. In vitro acetyl cholinesterase inhibitory activity of the essential oil from Acorus calamus and its main constituents. Planta Med 2007;73:283.

6. Small GW, Rabins PV, Barry PP, Buckholtz NS, DeKosky ST, Ferris SH, et al. Diagnosis and treatment of Alzheimer disease and related disorders. Consensus statement of the American Association for Geriatric Psychiatry, the Alzheimer's Association, and the American Geriatrics Society. JAMA 1997;278:1363-71.

7. Jensen SJ. Oxidative stress and free radicals. J Mol Struct 2003;666:387-92.

8. Sadiq A, Mahmood F, Ullah F, Ayaz M, Ahmad S, Haq FU, et al. Synthesis, anticholinesterase and antioxidant potentials of ketoesters derivatives of succinimides: A possible role in the management of Alzheimer's. Chem Cent J 2015;9:31.

9. Masella R, Di Benedetto R, Varì R, Filesi C, Giovannini C. Novel mechanisms of natural antioxidant compounds in biological systems: Involvement of glutathione and glutathione-related enzymes. J Nutr Biochem 2005;16:577-86.

10. Ayaz M, Junaid M, Subhan F, Ullah F, Sadiq A, Ahmad S, et al. Heavy metals analysis, phytochemical, phytotoxic and anthelmintic investigations of crude methanolic extract, subsequent fractions and crude saponins from Polygonum hydropiper L. BMC Complement Altern Med 2014;14:465.

11. Ullah F, Ayaz M, Sadiq A, Hussain A, Ahmad S, Imran M, et al. Phenolic, flavonoid contents, anticholinesterase and antioxidant evaluation of Iris germanica var Florentina. Nat Prod Res 2016;30:1440-4.

12. Ullah I, Subhan F Ayaz M, Shah R, Ali G, Haq IU, et al. Anti-emetic mechanisms of Zingiber officinale against cisplatin induced emesis in the pigeon; behavioral and neurochemical correlates. BMC Complement Altern Med 2015;15:34.

13. Nisar M, Mukarram Shah SM, Khan I, Sheema, Sadiq A, Khan S, et al. Larvicidal, insecticidal, brine shrimp cytotoxicity and anti-oxidant activities of Diospyros kaki (L.) reported from Pakistan. Pak J Pharm Sci 2015;28:1239-43.

14. Shah S, Sadiq A, Gul F. Antibacterial potential of methanolic extracts and sub-fractions of Teucrium stocksianum bioss collected from Malakand division 
Pakistan. Pharmacol online 2015;1:8-12.

15. Shah SM, Ahmad Z, Yaseen M, Shah R, Khan S, Shah SM, et al. Phytochemicals, in vitro antioxidant, total phenolic contents and phytotoxic activity of Cornus macrophylla wall bark collected from the North-West of Pakistan. Pak J Pharm Sci 2015;28:23-8.

16. Shah SM, Sadiq A, Shah SM, Ullah F. Antioxidant, total phenolic contents and antinociceptive potential of Teucrium stocksianum methanolic extract in different animal models. BMC Complement Altern Med 2014;14:181.

17. Zeb A, Sadiq A, Ullah F, Ahmad S, Ayaz M. Phytochemical and toxicological investigations of crude methanolic extracts, subsequent fractions and crude saponins of Isodon rugosus. Biol Res 2014;47:57.

18. Zeb A, Sadiq A, Ullah F, Ahmad S, Ayaz M. Investigations of anticholinestrase and antioxidant potentials of methanolic extract, subsequent fractions, crude saponins and flavonoids isolated from Isodon rugosus. Biol Res 2014;47:76.

19. Burits M, Bucar F. Antioxidant activity of Nigella sativa essential oil. Phytother Res 2000;14:323-8.

20. Islam S, Nasrin S, Khan MA, Hossain AS, Islam F, Khandokhar P, et al. Evaluation of antioxidant and anticancer properties of the seed extracts of Syzygium fruticosum Roxb. growing in Rajshahi, Bangladesh. BMC Complement Altern Med 2013;13:142.

21. Uddin MN, Afrin R, Uddin MJ, Uddin MJ, Alam AH, Rahman AA, et al. Vanda roxburghii chloroform extract as a potential source of polyphenols with antioxidant and cholinesterase inhibitory activities: Identification of a strong phenolic antioxidant. BMC Complement Altern Med 2015;15:195.

22. Perry N, Perry E. Aromatherapy in the management of psychiatric disorders: Clinical and neuropharmacological perspectives. CNS Drugs 2006;20:257-80.

23. Burkhill HM. Useful Plants of West Africa. $2^{\text {nd }}$ ed. University Press of Virginia: Royal Botanic Gardens, Kew: 1985. p. 130-2.

24. Rodolfo J, Kwon T. Xylopia aethiopica (Annonaceae): Chemistry, traditional uses and functional properties of an "African pepper", ACS, symp. Ser 2008;987:114-28.

25. Adegoke GO, Makinde O, Falade KO, Uzo-Peters PI. Extraction and characterization of antioxidants from Aframomum melegueta and Xylopia aethiopica. Euro Food Res Technol 2003;216:526-28.

26. Bak EN, Larsen MG, Moeller R, Nissen SB, Jensen LR, Nørnberg P, et al. Silicates eroded under simulated Martian conditions effectively kill bacteria-a challenge for life on mars. Front Microbiol 2017;8:1709.

27. Okigbo RN, Igwe DI. Antimicrobial effects of Piper guineense 'Uziza' and Phyllantus amarus 'ebe-benizo' on Candida albicans and Streptococcus faecalis. Acta Microbiol Immunol Hung 2007;54:353-66.

28. Fleischer TC. Xylopia aethiopica a rich: A chemical and biological perspective. J Uni Sci Technol 2003;23:24-31.

29. Woode E, Alhassan A, Chrissie SA. Effect of ethanolic fruit extract of Xylopia aethiopica on reproductive function of male rats. Int $\mathrm{J}$ Pharm Biomed Res $2011 ; 2: 161-5$.

30. Lambert RJ, Skandamis PN, Coote PJ, Nychas GJ. A study of the minimum inhibitory concentration and mode of action of oregano essential oil, thymol and carvacrol. J Appl Microbiol 2001;91:453-62.

31. Stein S, Mirokhin D, Tchekhovskoi DG. The NIST Mass Spectral Search Program for the NIST/EPA/NIH Mass Spectra Library; Standard Reference Data Program of the National Institute of Standards and Technology. Gaithersburg, MD, USA: NIST Standard Reference Database; 2002.

32. Adams R. Identification of Essential Oil Components by Gas Chromatography/ Mass Spectrometry. Carol Stream: Allured Publishing; 2007. p. 804

33. Ayaz M, Junaid M, Ahmed J, Ullah F, Sadiq A, Ahmad S, et al. Phenolic contents, antioxidant and anticholinesterase potentials of crude extract, subsequent fractions and crude saponins from Polygonum hydropiper L. BMC Complement Altern Med 2014; $14: 145$

34. Kamal Z, Ullah F, Ayaz M, Sadiq A, Ahmad S, Zeb A, et al. Anticholinesterase and antioxidant investigations of crude extracts, subsequent fractions, saponins and flavonoids of Atriplex laciniata L.: Potential effectiveness in Alzheimer's and other neurological disorders. Biol Res 2015;48:21.

35. Shahwar D, Muhammad AR, Afifa S, Madiha R, Faiza I, Chattha Merva J et al. Antioxidant potential of the extracts of Putranji varoxburghii, Conyzabon ariensis, Wood for diafruiticosa and Senecio chrysanthemoids. Afr. J. Biotechnol 2012;11:4288-95.

36. Tegang AS, Beumo TM, Dongmo PM, Ngoune LT. Essential oil of Xylopia aethiopica from Cameroon: Chemical composition, antiradical and in vitro antifungal activity against some Mycotoxigenic Fungi. J King Saud Uni Sci 2018;30:466-71.

37. Bakarnga-Via I, Hzounda JB, Fokou PV, Tchokouaha LR, Gary-Bobo M, Gallud A, et al. Composition and cytotoxic activity of essential oils from Xylopia aethiopica (Dunal) A. Rich, Xylopia parviflora (A. Rich) Benth.) and Monodora myristica (Gaertn) growing in chad and Cameroon. BMC Complement Altern Med 2014;14:125.
38. Olonisakin AM, Oladimeji O, Lajide L. Composition and antibacterial activity of steam distilled oils of Xylopia aethiopica and Syzygium aromaticum. J Eng Appl Sci 2007;2:236-40.

39. Gandhi S, Abramov AY. Mechanism of Oxidative Stress in Neurodegeneration. Oxidative Medicine and Cellular Longevity 2012:428010. [doi: 101155/2012/428010].

40. Kadri A, Zarai Z, Bekir A, Gharsallah N, Damak M, Gdoura R. Chemical composition and antioxidant activity of Marrubium vulgare $L$ essential oil from Tunisia. Afr J Biotech 2013;10:3908-14.

41. Ferreira A, Proença $C$, Serralheiro ML, Araújo ME. The in vitro screening for acetylcholinesterase inhibition and antioxidant activity of medicinal plants from Portugal. J Ethnopharmacol 2006;108:31-7.

42. Erel O. A novel automated direct measurement method for total antioxidant capacity using a new generation, more stable ABTS radical cation. Clin Biochem 2004;37:277-85.

43. Bondet $V$, Brand-Williams W, Berset C. Kinetics and mechanisms of antioxidant activity using the DPPH. Free radical method. LWT-Food Sci Technol 1997;30:609-15

44. Adefegha SA, Oboha G, Odubanjo T, Ogunsuyi OB. A comparative study on the antioxidative activities, anticholinesterase properties and essential oil composition of clove (Syzygium aromaticum) bud and Ethiopian pepper (Xylopia aethiopica). La Rivista Italiana Delle Sostanze Grasse 2015;92:257-68.

45. Ellman GL, Courtney KD, Andres V, Featherstone RM. A new and rapid colorimetric determination of acetyl cholinesterase activity. Biochem Pharmacol 1961;7:88-95

46. Chamberlin WM, Naser SA. Integrating theories of the etiology of Crohn's disease. on the etiology of Crohn's disease: Questioning the hypotheses. Med Sci Monit 2006;12:RA27-33

47. Cummings JL, Vinters HV, Cole GM, Khachaturian ZS. Alzheimer's disease: Etiologies, pathophysiology, cognitive reserve, and treatment opportunities. Neurology 1998;51:S2-17.

48. Valko M, Leibfritz D, Moncol J, Cronin MT, Mazur M, Telser J. Free radicals and antioxidants in normal physiological functions and human disease. Int $\mathrm{J}$ Biochem Cell Biol 2007;39:44-84.

49. Devasagayam TP, Tilak JC, Boloor KK, Sane KS, Ghaskadbi SS, Lele RD. Free radicals and antioxidants in human health: Current status and future prospects. J Assoc Physicians India 2004;52:794-804.

50. Scarpini E, Scheltens P, Feldman H. Treatment of Alzheimer's disease: Current status and new perspectives. Lancet Neurol 2003;2:539-47.

51. Howes MJ, Houghton PJ. Plants used in Chinese and Indian traditional medicine for improvement of memory and cognitive function. Pharmacol Biochem Behav 2003;75:513-27.

52. Chaiyana W, Okonogi S. Inhibition of cholinesterase by essential oil from food plant. Phytomedicine 2012;19:836-9

53. Orhan I, Aslan S, Kartal M, Şener B, Hüsnü Can Başer K. Inhibitory effect ofTurkish Rosmarinus officinalis $L$. on acetylcholinesterase and butyrylcholinesterase enzymes. Food Chem 2008;108:663-8.

54. Trinh NH, Hoblyn J, Mohanty S, Yaffe K. Efficacy of cholinesterase inhibitors in the treatment of neuropsychiatric symptoms and functional impairment in Alzheimer disease: A meta-analysis. JAMA 2003;289:210-6.

55. Savelev S, Okello E, Perry NS, Wilkins RM, Perry EK. Synergistic and antagonistic interactions of anticholinesterase terpenoids in Salvia lavandulaefolia essential oil. Pharmacol Biochem Behav 2003;75:661-8.

56. Ibano SM, Lima AS, Miguel MG, Pedro LG, Barroso JG, Figueiredo AC. Antioxidant, anti-5-lipoxygenase and antiacetylcholinesterase activities of essential oil and decoction waters of some aromatic plants. Rec Nat Prod 2012;6:35-48.

57. Steinberg GM, Mednick ML, Maddox J, Rice R, Cramer J. Hydrophobic binding site in acetyl cholinesterase. J Med Chem 1975;18:1056-61.

58. Ayedoun AM, Adoti BS, Sossou PV, Leclercq PA. Influence of fruit conservation methods on the essential oil composition of Xylopia aethiopica (Dunal) A. Richard from Benin. Flav Fragr J 1996;11:245-50.

59. Tairu AO, Hofmann T, Schieberle P. Characterization of the key aroma compounds in dried fruits of the West African peppertree Xylopia aethiopica (Dunal) A. Rich (Annonaceae) using aroma extract dilution analysis. J Agric Food Chem 1999;47:3285-7.

60. Tatsadjieu LN, Essia Ngang JJ, Ngassoum MB, Etoa FX. Antibacterial and antifungal activity of Xylopia aethiopica, Monodora myristica, Zanthoxylum zanthoxyloides and Zanthoxylum leprieurii from Cameroon. Fitoterapia 2003;74:469-72.

61. Ekundayo O. A review of the volatiles of the Annonaceae. J Essent Oil Res 1989;1:223-31.

62. Onayade-Sontan AO. Analysis of the Essential Oils of Some Plants Used in Traditional Medicine in Nigeria. Ph.D. Thesis, State University of Leiden; 1991.

63. Ogan AU. West African medicinal plants. V. Isolation of cuminal from Xylopia 
aethiopica. Phytochemistry 1971;10:2823-4.

64. Karioti A, Hadjipavlou-Litina D, Mensah ML, Fleischer TC, Skaltsa H. Composition and antioxidant activity of the essential oils of Xylopia aethiopica (Dun) A. Rich. (Annonaceae) leaves, stem bark, root bark, and fresh and dried fruits, growing in Ghana. J Agric Food Chem 2004;52:8094-8.

65. Loizzo MR, Tundis R, Menichini F, Menichini F. Natural products and their derivatives as cholinesterase inhibitors in the treatment of neurodegenerative disorders: An update. Curr Med Chem 2008;15:1209-28.

66. Stamatis $H$, Sereti $V$, Kolisis F. Studies on the enzymatic synthesis of lipophilic derivatives of natural antioxidants. J Am Oil Chem Soc 1999;76:1505-10.

67. Mehendale S, Kilari A, Dangat K, Taralekar V, Mahadik S, Joshi S. Fatty acids, antioxidants, and oxidative stress in pre-eclampsia. Int J Gynaecol Obstet 2008; 100:234-8

68. Decker EA, Warner K, Richards MP, Shahidi F. Measuring antioxidant effectiveness in food. J Agric Food Chem 2005;53:4303-10.

69. Sengupta A, Ghosh M. Comparison of native and capric acid-enriched mustard oil effects on oxidative stress and antioxidant protection in rats. $\mathrm{Br} \mathrm{J}$ Nutr 2012;107:845-9

70. Öztürk M, Duru ME, Kivrak S, Mercan-Doğan N, Türkoglu A, Özler MA In vitro antioxidant, anticholinesterase and antimicrobial activity studies on three Agaricus species with fatty acid compositions and iron contents: A comparative study on the three most edible mushrooms. Food Chem Toxicol 2011;49:1353-60.

71. Yi BH, Kim DH. Antioxidant activity of maltol, kojic acid, levulinic acid, furfural, 5-hydroxymethyl furfural and pyrazines. Korean J Food Sci Technol $1982 ; 14: 265-70$

72. Tepe B, Daferera D, Sokmen A, Sokmen M, Polissiou M. Antimicrobial and antioxidant activities of the essential oil and various extracts of Salvia tomentosa Miller (Lamiaceae). Food Chem 2005;90:333-40.

73. Ayaz M, Junaid M, Ullah F, Sadiq A, Khan MA, Ahmad W, et al. Comparative chemical profiling, cholinesterase inhibitions and anti-radicals properties of essential oils from Polygonum hydropiper L: A preliminary anti- Alzheimer's study. Lipids Health Dis 2015;14:141. 